\title{
Analisis Hubungan Kemahiran dengan Kecekapan Teknik Firma Perkhidmatan di Malaysia
}

\author{
(Analysis of Relationship between Skills and Technical Efficiency of Service Firm in Malaysia)
}

\author{
Noorasiah Sulaiman \\ Nursaliha Abd Ghafar \\ (Fakulti Ekonomi dan Pengurusan, Universiti Kebangsaaan Malaysia)
}

\begin{abstract}
ABSTRAK
Kajian ini menganalisis hubungan antara kemahiran dengan tahap kecekapan teknik firma dalam sektor perkhidmatan di Malaysia. Kemahiran dikategorikan kepada enam dimensi, iaitu kemahiran berkomunikasi secara efektif; kemahiran berfikir secara kritis dan menyelesaikan masalah; kemahiran bekerja secara berpasukan; kemahiran etika dan moral dalam profesion; kemahiran keusahawanan; dan kemahiran pengurusan. Kajian ini berasaskan 130 buah firma perkhidmatan yang diperoleh daripada kajian lapangan pada 2014. Objektif kajian ialah menganalisis hubungan antara kemahiran dengan tahap kecekapan firma. Kajian ini menggunakan analisis sempadan stokastik (SFA) dalam mengukur tahap kecekapan teknik firma, sementara model persamaan berstruktur (SEM) menggunakan perisian SmartPLS dalam menganalisis hubungan antara kemahiran dan kecekapan. Dapatan menunjukkan tahap kecekapan teknik firma perkhidmatan secara relatifnya adalah rendah. Selanjutnya, hanya kemahiran bekerja secara berpasukan sahaja yang secara positif mempengaruhi tingkat kecekapan firma, manakala kemahiran beretika dan moral dalam profesion dan kemahiran berkomunikasi secara efektif mempengaruhi tahap kecekapan secara negatif dalam sektor yang dikaji.
\end{abstract}

Kata kunci: Kecekapan teknik; kemahiran; firma perkhidmatan; analisis sempadan stokastik; SmartPLS

ABSTRACT

This study analyzes the relationship between skills and firms'technical efficciency in the services sector in Malaysia. Skills are categorized into six dimensions, namely effective communication skills; critical thinking skills and problem solving; teamwork skills; ethical and moral skills in the profession; entrepreneurial skills; and management skills. This study is based on 130 service firms obtained from field studies in 2014. The objective of the study is to analyze the relationship between skills and firm technical efficiency. This study uses stochastic frontier analysis (SFA) in measuring the firm's technical efficiency, while the structural equation model (SEM) uses the SmartPLS software in analyzing the relationship between skills and efficiency. The findings show that the level of technical efficiency of the service firm is relatively low. Furthermore, only the teamwork skills that positively influence the firm's level of efficiency, while ethical and moral skills in the profession and effective communication skills negatively affect level of efficiency in the sector studied.

Keywords: Technical efficiency; skills; service firm; stochastic frontier analysis; SmartPLS

\section{PENGENALAN}

Globalisasi yang telah mengubah ekonomi daripada berasaskan pengeluaran kepada berasaskan pengetahuan menekankan kepada tenaga kerja yang berpengetahuan, berkemahiran dan mampu mengaplikasi pengetahuan yang dimiliki dalam proses pengeluaran, di samping pencapaian output yang tinggi (World Bank 2003). Seiring dengan kemajuan dalam teknologi komunikasi dan maklumat, Malaysia dilihat telah mengalami perubahan dalam ekonomi, khususnya dari segi keperluan kemahiran tenaga kerja (Constantine 2006). Justeru itu, kemunculan ekonomi berasaskan pengetahuan dan hubungan antara kemahiran dengan pencapaian prestasi di tempat kerja telah menyumbang kepada kepentingan dan peningkatan permintaan untuk kemahiran generik (Sung \& Ramos 2014; Grugulis \& Stoyanova 2011; Ashton \& Sung 2002; Field \& Mawer 1996), di mana tenaga kerja yang kompeten dan lengkap dengan pelbagai kemahiran diperlukan dalam pasaran (World Bank 2003). Selain daripada kecekapan teknik, kemahiran kini dianggap penting bagi perusahaan perniagaan pada abad ke-21.

Statistik menunjukkan jumlah tenaga kerja mahir di negara ini masih rendah. Dilaporkan purata tenaga kerja mahir adalah sekitar $25.0 \%$ daripada jumlah keseluruhan guna tenaga bagi tempoh 2010 hingga 2015 (Banci Penyiasatan Tenaga Buruh 2015). Kajian empirik turut menunjukkan tenaga kerja mahir masih lagi kekurangan dan ini menjadi salah satu faktor utama yang menyumbang kepada ketidakcekapan sesebuah firma/organisasi. Ini dibuktikan melalui kajian yang dibuat oleh Abdullah (1997), Ismail dan Nyet Fung (2002), Ismail et al. (2015) dan Sulaiman, Ismail dan Saukani (2016). Di samping keperluan terhadap tenaga kerja mahir, keperluan terhadap kemahiran generik (soft skills) dan bakat istimewa turut diutamakan oleh majikan dalam mengambil pekerja (Said 2006). Majikan kini lebih mengutamakan kepelbagaian 
dalam kemahiran generik yang dimiliki oleh pekerja dan ini menjadi satu cabaran kepada pencari pekerjaan.

Justeru itu, pekerja yang memiliki kemahiran yang pelbagai dianggap sebagai pekerja yang produktif dan cekap, malah penyumbang kepada daya saing sesebuah firma/organisasi, industri mahupun sektor ekonomi (Yussof et al. 2014). Oleh kerana tahap kecekapan menjadi penentu kepada daya saing maka prestasi sesebuah firma sering dikaitkan dengan kecekapan dan produktiviti (Porter 2004). Kajian empirik telah membuktikan bahawa kemahiran pekerja berupaya mempengaruhi tingkat kecekapan firma/organisasi. Kajian Kisaka, Kising dan Wafubwa (2014) terhadap firma perbankan di Kenya mendapati bahawa tahap kecekapan firma meningkat jika mengambil pekerja, khususnya pengurus yang mempunyai tingkat kemahiran soft skills yang tinggi, di samping mempunyai kualiti modal manusia yang baik, iaitu tahap pendidikan, tingkat pengalaman, dan mengikuti latihan. Dapatan kajian ini konsisten dengan dapatan kajian Jones (1994), Kirkley, Squires dan Strand (1998), Gallacher (2001), Ugur (2004) dan Bottazzi, Secchi dan Tamagni (2006) yang turut mengiktiraf bahawa tahap kemahiran pengurus-pengurus adalah faktor utama yang menyumbang kepada tahap kecekapan firma. Kajian Kirkley et al. (1998) dan Viswanathan et al. (2000) juga menunjukkan kemahiran mengurus dalam kalangan ketua juragan/ketua nelayan menyumbang kepada tahap kecekapan yang tinggi dalam mengendalikan sesebuah kapal perikanan.

Di Malaysia, kajian berhubung tahap kecekapan firma tidak asing lagi dalam kalangan para pengkaji. Antaranya kajian yang dibuat oleh Abu Mansor dan Radam (2000); Md. Saad et al. (2007); Ismail dan Zainal Abidin (2006); Ismail dan Sulaiman (2007); Sulaiman dan Ismail (2007); Ismail dan Tendot (2008); Radam et al. (2009); Adni, Omar dan Mohd Tarmizi (2012); Salleh (2012); Applanaidu et al. (2014); Samsudin et al. (2014); Sulaiman, Yusof dan Ismail (2015); Abdullah et al. (2017) dan Abdullah, Wei Sieng dan Isa (2018). Sungguhpun kajian lepas menganalisis secara khusus faktor-faktor yang menentukan tingkat kecekapan firma, namun aspek kemahiran, khususnya kemahiran generik tidak dikaji secara spesifik. Kesemua kajian yang dinyatakan di atas hanya menganalisis faktor-faktor penentu (selain kemahiran) kepada kecekapan firma. Antara faktor penentu yang lazim dianalisis oleh ramai pengkaji ialah tahap penggunaan teknologi yang digunakan (ini termasuk tahap penggunaan komputer) (Abu Mansor \& Radam 2000; Sulaiman \& Ismail 2007; Abdullah et al. 2017; Abullah et al. 2018), saiz firma (Sulaiman \& Ismail 2007; Mohd Noor \& Ismail 2007; Abullah et al. 2018), tingkat upah (Abdullah et al. 2017); tahap pendidikan pengusaha (Sulaiman \& Ismail 2007); tahap pendidikan pekerja (Abullah et al. 2018), perbelanjaan latihan dan perbelanjaan untuk penyelidikan dan pembangunan (Ismail \& Sulaiman 2007; Abullah et al. 2018)

Justeru itu, kajian ini menganalisis tahap kecekapan firma dalam konteks berbeza di mana kemahiran generik dijangka mempunyai pengaruh yang besar terhadap kecekapan. Ini kerana aspek kemahiran pekerja dinilai secara spesifik dengan mengkategorikan kemahiran kepada enam dimensi, iaitu kemahiran berkomunikasi secara efektif, kemahiran berfikir dan menyelesaikan masalah, kemahiran bekerja secara berpasukan, kemahiran etika dan moral dalam profesion, kemahiran pengurusan dan kemahiran keusahawanan. Atas justifikasi di atas, masih terdapat jurang yang perlu dikaji dan dapatan kajian ini menyumbang kepada bidang pengkajian kecekapan dan hubungnnya dengan aspek kemahiran secara lebih spesifik. Di samping itu, kajian ke atas firma perkhidmatan adalah amat relevan dalam konteks Malaysia disebabkan sektor ini adalah penyumbang terbesar kepada guna tenaga dan keluaran dalam negara kasar (KDNK) negara (Banci Penyiasatan Tenaga Buruh 2017; Laporan Ekonomi 2017/2018). Objektif kajian ini ialah menganalisis hubungan antara pelbagai kemahiran generik dengan tingkat kecekapan firma perkhidmatan menggunakan Model Persamaan Berstuktur (SEM).

Perbincangan dalam penulisan ini di struktur kepada lima bahagian. Bahagian seterusnya, kedua ialah perbincangan kajian literatur mengenai tahap kecekapan dan keperluan kemahiran dengan tahap kecekapan firma. Bahagian ketiga adalah metodologi kajian yang mengandungi penjelasan tentang sumber data, keterangan bagi soal selidik, penganggaran tahap kecekapan dan pembinaan hipotesis. Bahagian keempat, dapatan kajian yang terbahagi kepada analisis deskriptif mengenai profil firma dan pengusaha, diikuti oleh keputusan ujian kesahan dan ujian kebolehpercayaan. Selanjutnya, perbincangan mengenai keputusan hipotesis bagi tingkat kecekapan firma yang dikaji dengan setiap aspek kemahiran pekerja. Di akhir penulisan ialah kesimpulan bagi kajian ini.

\section{KAJIAN LITERATUR}

\section{TAHAP KECEKAPAN TEKNIK}

Kecekapan teknik merujuk kepada kemampuan firma untuk mengeluarkan output yang paling maksima dengan menggunakan satu set faktor pengeluaran (input) yang diberi. Farrell (1957) mendefinisikan kecekapan teknik sebagai penghasilan output yang berasaskan beberapa input yang digunakan dalam sesuatu pengeluaran. Kajian terawal oleh Bessent dan Bessent (1979) telah membandingkan tahap kecekapan sekolah-sekolah di Amerika Syartikat. Selanjutnya, kajian Isabel dan Tatiane (2011) turut menganalisis tahap kecekapan sekolahsekolah awam di Brazil. Di bidang kesihatan pula, kajian Nunamaker dan Lewin (1983) dan Sherman (1984) telah mengukur tahap kecekapan perkhidmatan hospital. Selanjutnya, kajian oleh Hollingsworth (2008) dan Nayar dan Ozcan (2008), sementara kajian Yauheniyavarabyova dan Jonasschreyögg (2013) telah mengkaji tahap kecekapan hospital awam secara lebih meluas, iaitu di negara-negara OECD. Kajian Baten, Kamil dan Fatama (2009) dan Fu, Sun dan Zhou (2011) pula telah mengukur tahap kecekapan teknik firma di negara Bangladesh dan 
China. Sektor kewangan juga turut diliputi menerusi kajian yang dibuat oleh Chen, Chen dan Peng (2008) yang mengkaji tahap kecepakan firma perkhidmatan kewangan.

Di Malaysia sendiri, kajian kecekapan teknik terhadap firma di sektor pembuatan mahupun sektor perkhidmatan tidak asing lagi kepada pengkaji tempatan. Antaranya ialah kajian Ismail dan Zainal Abidin (2006), diikuti kajian Ismail dan Sulaiman (2007) dan Ismail dan Tendot (2008), terhadap tingkat kecekapan teknik firma pembuatan. Kajian terkini oleh Abdullah et al. (2017) dan Abullah et al. (2018). Sementara kajian terhadap kecekapan teknik firma di dalam sektor perkhidmatan turut dibuat oleh Sulaiman dan Ismail (2007). Sektor pendidikan turut dikaji menerusi kajian Salleh (2012) dan Sulaiman, Yusof dan Ismail (2015) mengkaji tahap kecekapan teknik di institusi pengajian tinggi. Sektor perkhidmatan kewangan yang melibatkan tahap kecekapan dalam kalangan firma perbankan turut dikaji oleh Radam et al. (2009), firma perkhidmatan insuran (Abu Mansor \& Radam 2000; Md. Saad et al. 2007; Adni et al. 2012), sementara Applanaidu et al. (2014) dan Samsudin et al. (2014) membuat kajian ke atas sektor perkhidmatan hospital di Malaysia.

Sungguhpun terdapat banyak kajian yang mengkaji tahap kecekapan teknik firma di sektor pembuatan dan perkhidmatan, namun analisis lanjut hanya tertumpu kepada faktor-faktor penentu bagi kecekapan, tanpa mengkaji hubungan antara tahap kecekapan dengan aspek keperluan kemahiran pekerja secara lebih spesifik. Antara faktor penentu bagi tahap kecekapan firma yang di analisis oleh ramai pengkaji ialah tahap penggunaan teknologi yang digunakan oleh firma (ini termasuk tahap penggunaan komputer), saiz firma (berdasarkan jumlah pekerja atau jumlah modal dimiliki), status firma (firma utama atau subkontrak), tempoh firma beroperasi, jumlah aset dimiliki, tahap pendidikan pengusaha, peratus perbelanjaan untuk latihan dan peratus perbelanjaan untuk penyelidikan dan pembangunan (Abu Mansor \& Radam 2000; Md. Saad et al. 2007; Ismail \& Zainal Abidin 2006; Ismail \& Sulaiman 2007; Sulaiman \& Ismail 2007; Ismail \& Tendot 2008; Radam et al. 2009; Adni et al. 2012; Salleh 2012; Applanaidu et al. 2014; Samsudin et al. 2014; Sulaiman et al. 2015; Abdullah et al. 2017; Abullah et al. 2018).

\section{KEPERLUAN KEMAHIRAN DAN TAHAP KECEKAPAN}

Kemahiran dilihat begitu kritikal dalam dunia pekerjaan semasa yang bersifat global dan sentiasa mengalami perubahan dari sudut penggunaan teknologi yang berubah begitu pantas (World Bank Report 2003). Dalam konteks Malaysia yang meletakkan pencapaian status sebuah negara maju dan kekal berdaya saing di peringkat antarabangsa, sudah pasti memerlukan sumber manusia yang berkualiti tinggi dalam pelbagai sektor ekonomi, khususnya sektor perkhidmatan yang menjadi skop kajian ini. Sumber manusia yang cekap dan berkualiti mampu menggunakan pengetahuan dan menguasai perubahan teknologi yang pantas menjadi keperluan para majikan pada era globalisasi, khususnya bagi Revolusi Perindustrian 4.0 (IR4.0) (Schwab 2017). Pekerja berpengetahuan (knowledge-worker) diperlukan untuk memenuhi keperluan industri dan ini selari dengan kehendak majikan untuk menggerakkan perniagaan seiring dengan pertumbuhan ekonomi (Husain \& Mustapha 2009).

Justeru itu, bukan sahaja kelayakan akademik yang cemerlang diperlukan, malah pencari-pencari kerja perlu menguasai pelbagai kemahiran seperti kemahiran menyelesaikan masalah, kemahiran berfikir secara kritis dan kreatif, kemahiran komunikasi dan seumpamanya. Pernyataan ini disokong oleh ACNielsen (2000) yang melakukan kajian mengenai tahap kepuasan majikan terhadap kemahiran graduan dalam aspek pemilihan pekerja dalam industri. Kajiannya mendapati kebanyakan majikan lebih mengutamakan calon yang memiliki dan menguasai kemahiran kreatif, kebolehan semula jadi/ bakat, kemahiran komunikasi, kemahiran menyelesaikan masalah dan kebolehan bekerja secara berkumpulan. Dapatan kajian Jackling dan Lange (2009) juga mendapati majikan lebih mengutamakan kemahiran generik berbanding kemahiran teknikal.

Dari sudut pandangan majikan, kriteria pengambilan pekerja amat diutamakan, khususnya berkaitan hal yang dapat meningkatkan kecekapan pengurusan organisasi tanpa mengira organisasi adalah sektor awam mahupun swasta (ACNielsen 2000; Makhbul \& Hasun 2007). Dapatan kajian Jajri et al. (1992) terhadap majikan di Malaysia menunjukkan sektor awam lebih mementingkan pengetahuan am, kepimpinan, kemahiran berkomunikasi dan keupayaan menulis lebih daripada bidang kursus semasa memilih pekerja. Kajian Md Zabid dan Samsinar (1996) turut bersetuju bahawa kedua-dua organisasi awam dan swasta mempunyai pandangan yang berbeza dalam pemilihan pekerja. Walau bagaimanapun, majikan organisasi swasta menunjukkan jangkaan yang tinggi terhadap keupayaan calon dalam memilih pekerja berbanding majikan organisasi awam.

Sementara hasil kajian Archer dan Davison (2008) menunjukkan hampir kesemua majikan (86.0\%) menganggap kemahiran komunikasi yang baik adalah satu kemahiran yang penting. Tambahan lagi, mereka berpendapat bahawa kemahiran yang berbentuk soft skills seperti kerjasama berpasukan juga penting malah lebih penting daripada kebanyakan kemahiran yang berbentuk hard skills. Dapatan ini selari dengan dapatan kajian Arsat dan Abd Kadir (2010) bahawa majikan lebih mengutamakan kemahiran generik dalam faktor pemilihan jurutera mengikut perspektif industri pembinaan di Malaysia. Mereka lebih mengutamakan kemahiran berkomunikasi, pemikiran kritis dan kemahiran menyelesaikan masalah, kerja berpasukan dan etika, moral dan profesional dalam pengambilan jurutera.

Berbeza dengan sektor perbankan, faktor-faktor pemilihan pekerja lebih memihak kepada kokurikulum 
dan kursus yang diambil oleh calon (Ameerudin 2001). Sementara aspek kemahiran calon dalam berkomunikasi, diikuti oleh faktor latihan industri dan kebolehan kerja berpasukan dan personaliti dinyatakan sebagai faktor sekunder. Di sektor perkilangan pula, kriteria pengalaman, di samping faktor personaliti dan keterampilan, jantina dan kelayakan akademik amat dipentingkan terutama dalam pemilihan pekerja peringkat pengurusan (Makhbul \& Hasun (2007).

Dapatan kajian Jajri et al. (1992), Md Zabid dan Samsinar (1996), ACNielsen (2000), Jackling dan Lange (2009), Archer dan Davison (2008) dan Arsat dan Abd Kadir (2010) adalah serupa di mana kemahiran generik lebih diutamakan oleh majikan dalam pengambilan pekerja. Sebaliknya dapatan kajian Ameerudin (2001) berbeza kerana majikan lebih mengutamakan kokurikulum dan kursus yang diambil oleh calon semasa di universiti, sementara dapatan kajian Makhbul dan Hasun (2007) pula majikan lebih mementingkan kualiti modal manusia. Berdasarkan dapatan kajian yang diperoleh, dapat disimpulkan bahawa kriteria pemilihan pekerja oleh majikan didapati sedikit berbeza mengikut keperluan industri dan jenis pekerjaan, namun kebanyakan majikan bersetuju bahawa aspek kemahiran soft skills lebih diutamakan dalam pengambilan pekerja. Kebanyakan majikan juga lebih mengutamakan kemahiran generik yang boleh-pindah (transferable skills) seperti kemahiran komunikasi (termasuk kemahiran berkomunikasi dalam bahasa Inggeris), kreativiti, pemikiran kritis dan kemahiran menyelesaikan masalah.

Berhubung aspek kemahiran dan tingkat kecekapan firma, beberapa kajian empirik telah mengesahkan bahawa kemahiran pekerja berupaya mempengaruhi tingkat kecekapan firma/organisasi. Kajian Kisaka et al. (2014) terhadap firma perbankan di Kenya mendapati tahap kecekapan firma meningkat jika mengambil pekerja, khususnya pengurus yang mempunyai tingkat kemahiran soft skills yang tinggi, di samping mempunyai kualiti modal manusia yang baik, iaitu tahap pendidikan, tingkat pengalaman, dan kekerapan mengikuti latihan. Dapatan kajian ini konsisten dengan dapatan kajian Jones (1994), Kirkley et al. (1998), Gallacher (2001), Ugur (2004) dan Bottazzi et al. (2006) yang turut mengiktiraf bahawa tahap kemahiran pengurus-pengurus adalah faktor utama yang menyebabkan tahap kecekapan firma-firma berbeza. Kajian Kirkley et al. (1998) dan Viswanathan et al. (2000) juga menunjukkan ketua juragan/ketua nelayan yang mempunyai kemahiran pengurusan mempunyai tahap kecekapan yang tinggi dalam mengendalikan sesebuah kapal perikanan.

\section{METODOLOGI KAJIAN}

\section{SUMBER DATA}

Kajian ini menggunakan data soal selidik yang telah diedarkan di negeri-negeri yang mewakili zon/wilayah di Malaysia. Zon tengah diwakili oleh Wilayah Persekutuan
Kuala Lumpur dan Selangor. Negeri Pahang dan Terengganu mewakili zon timur, sementara zon selatan dan zon utara masing-masing diwakili oleh negeri Melaka dan Johor, dan negeri Kedah dan Pulau Pinang. Kesemua responden adalah firma yang berdaftar di bawah Persekutuan Majikan-Majikan Malaysia (MEF). Kaedah pemilihan sampel dibuat berasaskan teknik persampelan rawak berstrata (stratified random sampling technique). Sejumlah 1000 borang soal selidik telah diedar melalui pos dan e-mel, di mana majikan/pengurus/pegawai sumber manusia adalah pihak yang bertanggungjawab untuk melengkapkan borang kaji selidik tersebut. Sebanyak 250 borang soal selidik firma sektor perkhidmatan telah berjaya dikutip berasaskan maklumat pada 2014. Daripada jumlah tersebut, hanya 130 responden/firma (52.0\%) yang dapat dianalisis berdasarkan maklumat yang lengkap.

\section{SOAL SELIDIK DAN PENGUKURAN PEMBOLEHUBAH}

Borang soal selidik yang digunakan dalam kajian ini terbahagi kepada empat bahagian. Bahagian pertama mempunyai maklumat latar belakang majikan/pengurus firma/syarikat. Ini meliputi maklumat jantina, bangsa, tahap pendidikan dan tempoh pengalaman. Bahagian kedua pula mempunyai maklumat firma/syarikat yang meliputi tempoh pengoperasian, status syarikat, sektor organisasi/syarikat, nilai modal permulaan dan modal fizikal, peratus pemilikan modal syarikat, bilangan pekerja, dan nilai hasil tahunan. Bahagian ketiga pula berkenaan dengan impak globalisasi terhadap keperluan kemahiran pekerja. Bahagian ini terdiri daripada maklumat keperluan pekerja di dalam syarikat yang meliputi maklumat jumlah pekerja profesional, separa profesional dan teknikal, pekerja perkeranian dan pekerja asas.

Bahagian akhir dalam borang soal selidik adalah maklumat keperluan kemahiran yang diperlukan oleh majikan/pengurus dalam pengambilan pekerja di organisasi mereka. Komponen kemahiran bertujuan mengkaji sejauh manakah kemahiran-kemahiran tertentu penting kepada sesebuah organisasi, khususnya untuk mempertingkat produktiviti dan kecekapan. Aspek kemahiran yang dikaji melibatkan kemahiran generik sahaja. Ini meliputi sembilan dimensi kemahiran, iaitu kemahiran berkomunikasi secara efektif, kemahiran berfikir dan menyelesaikan masalah, kemahiran bekerja secara berpasukan, kemahiran pembelajaran berterusan dan pengurusan maklumat, kemahiran keusahawanan, kemahiran etika dan moral dalam profesion, kemahiran kepimpinan, kemahiran pengurusan, dan kemahiran sosial. Skala Likert daripada 1 hingga 7 mengukur tahap kemahiran pekerja dalam sesebuah organisasi.

\section{PENGANGGARAN TAHAP KECEKAPAN TEKNIK}

Kajian ini mengunakan model pengeluaran analisis perbatasan stokastik (SFA) dalam mengukur tahap 
kecekapan teknik firma yang dikaji. Berasaskan model SFA, penganggaran bagi tahap kecekapan teknik adalah berasaskan fungsi pengeluaran Cobb-Douglas. Secara umum, fungsi pengeluaran Cobb-Douglas adalah seperti berikut:

$$
Y=A X_{1}^{\alpha} A X_{2}^{\beta} \cdots X_{n}^{\varpi}
$$

Dalam bentuk logaritma, fungsi di atas boleh ditulis seperti berikut:

$$
\ln Y_{i}=\ln A+\alpha \ln X_{1}+\beta \ln X_{2}+\cdots \varpi \ln X_{n}
$$

Secara konsepnya, kecekapan dalam menghasilkan output boleh ditentukan apabila firma mengeluar pada tahap di atas sempadan pengeluaran, iaitu dengan menganggarkan fungsi pengeluaran daripada sampel atau firma yang mempunyai prestasi terbaik. Bagi firma yang beroperasi di bawah sempadan pengeluaran, firma dianggap sebagai tidak cekap. Model SFA yang digunakan dalam kajian ini adalah berdasarkan model Battese dan Coelli (1995), Coelli (1996) dan Coelli et al. (1998). Model ini secara umumnya mengukur hubungan antara pembolehubah bersandar, iaitu output dengan pembolehubah bebas, iaitu input-input pengeluaran. Bagi kajian ini, pembolehubah output diwakili oleh nilai/hasil jualan firma, sementara pemboleh input ialah jumlah modal fizikal dan jumlah buruh/bilangan pekerja firma. Model SFA lazim digunakan oleh pengkaji untuk mengukur tahap kecekapan dan ketidakcekapan teknik firma (Battese \& Coelli 1995; Kumbhakar et al. 1991; Reifschneider \& Stevenson 1991; Huang \& Liu 1994).

Oleh itu, model SFA yang berasaskan fungsi pengeluaran Cobb-Douglas diaplikasi menerusi program FRONTIER (Coelli 1996) bagi kajian ini adalah seperti berikut:

$$
\ln \left(Y_{i}\right)=\beta_{0}+\beta_{1} \ln K_{i}+\beta_{2} \ln L_{i}+v_{i}-u_{i}
$$

Dengan: $\mathrm{Y}$ adalah nilai/hasil jualan setahun (RM)

$\mathrm{K}$ adalah nilai modal fizikal semasa (RM)

L adalah bilangan pekerja

$\mathrm{v}$ adalah pembolehubah rawak dan diandaikan bebas dan bertaburan normal, $N\left(0, \sigma_{i}^{2}\right)$

$\mathrm{u}$ adalah pembolehubah rawak yang tidak negatif dan pembolehubah ini merujuk kepada kesan ketidakcekapan teknik dalam pengeluaran bagi firma yang dikaji

i adalah firma $\mathrm{i}$

Bagi mengukur tahap kecekapan, nilai $\sigma^{2}$ digunakan dengan membentuk hipotesis berikut: $\mathrm{H}_{0}: \sigma^{2}=0$ dan $\mathrm{H}_{1}: \sigma^{2} \neq 0$. Sekiranya hipotesis nol diterima, maka tiada ketidakcekapan teknik dalam proses pengeluaran, atau dengan kata lain semua firma beroperasi pada tahap yang cekap. Sebaliknya, jika hipotesis nol ditolak, maka terdapat firma yang tidak beroperasi dengan cekap. Dalam analisis ini, indeks kecekapan teknik yang diperoleh adalah bernilai antara sifar hingga satu digunakan sebagai pembolehubah bersandar dalam model seterusnya menggunakan perisian SmartPLS.

\section{PEMBINAAN HIPOTESIS}

Rajah 1 menunjukkan model konsep yang menerangkan hubungan antara jenis kemahiran pekerja sebagai pembolehubah bebas dalam mempengaruhi tahap kecepakan teknik firma. Hubungan antara kedua-duanya berlaku secara langsung, iaitu setiap jenis kemahiran pekerja dijangka mempengaruhi tahap kecekapan teknik firma yang dikaji.

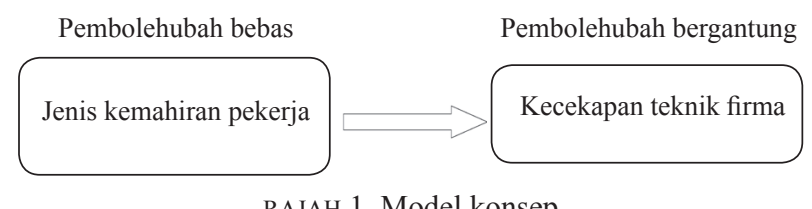

Berasaskan Rajah 1, kajian ini membentuk beberapa hipotesis bagi setiap kemahiran pekerja yang dikaji dalam kajian ini dengan tahap kecekapan teknik firma. Kesemua hipotesis dijangka mempunyai hubungan yang positif.

$\mathrm{H}_{1} \quad$ Kemahiran bekerja secara berpasukan secara positif mempengaruhi tahap kecekapan teknik firma.

$\mathrm{H}_{2}$ Kemahiran berfikir dan menyelesaikan masalah secara positif mempengaruhi tahap kecekapan teknik firma.

$\mathrm{H}_{3}$ Kemahiran beretika dan moral dalam profesion secara positif mempengaruhi tahap kecekapan teknik firma.

H Kemahiran berkomunikasi secara efektif secara positif mempengaruhi tahap kecekapan teknik firma

$\mathrm{H}_{5} \quad$ Kemahiran keusahawanan secara positif mempengaruhi tahap kecekapan teknik firma.

$\mathrm{H}_{6} \quad$ Kemahiran pengurusan secara positif mempengaruhi tahap kecekapan teknik firma.

Kajian ini menggunakan perisian SmartPLS bagi menganalisis hubungan antara pelbagai dimensi kemahiran pekerja sebagai pembolehubah tidak bersandar dengan tahap kecekapan teknik firma yang mewakili pembolehubah bersandar. Berasaskan model konsep seperti di dalam Rajah 1, kajian ini mempunyai enam konstruk dimensi kemahiran yang berasaskan pandangan majikan terhadap keperluan kemahiran pekerja yang diperlukan dalam sesebuah organisasi. Data yang dikumpul bagi kesemua item yang mewakili setiap konstruk adalah dalam bentuk skala likert, iaitu skala 1 hingga 7 , dengan skala 1 mewakili tahap sangat tidak penting dan skala 7 mewakili tahap amat penting terhadap keperluan kemahiran.

\section{DAPATAN KAJIAN}

\section{TAHAP KECEKAPAN TEKNIK FIRMA}

Jadual 1 menunjukkan keputusan penganggaran tingkat kecekapan teknik bagi firma perkhidmatan di Malaysia. Keputusan regresi menunjukkan bahawa kedua-dua parameter yang dianggarkan, iaitu modal fizikal $(K)$ dan jumlah pekerja $(L)$ adalah signifikan dan mempengaruhi 
nilai jualan firma secara positif. Nilai koefisien modal fizikal adalah 0.433 menunjukkan bahawa apabila berlaku peningkatan $1 \%$ dalam input $K$ menyebabkan berlaku peningkatan dalam nilai jualan firma sebanyak $0.433 \%$. Bagi input $L$ pula, peningkatan 1\% dalam input buruh akan menyebabkan peningkatan dalam nilai jualan hanya $0.259 \%$.

Bagi parameter gamma $(\gamma)$, hasil penganggaran menunjukkan parameter ini bernilai 0.569 dan signifikan pada aras keertian 5\% (lihat Jadual 1). Nilai ini memberi maksud kesan ketidakcekapan teknik memberikan sumbangan yang signifikan dan sederhana terhadap tahap dan perubahan pengeluaran firma dalam sektor perkhidmatan yang dikaji. Di samping itu, nilai sigma kuasa dua $\left(\sigma^{2}\right)$ menunjukkan nilai sebanyak 1.215 dan signifikan pada aras keertian $1 \%$ memberi maksud bahawa hipotesis nol ditolak. Ini bermakna terdapat firma dalam kajian ini yang tidak beroperasi secara cekap. Namun demikian, purata skor kecekapan teknik bagi keseluruhan firma yang dikaji sebanyak 0.576 adalah melebihi nilai purata. Ini menggambarkan bahawa firma perlu meningkatkan outputnya sebanyak $42.4 \%$ berasaskan penggunaan jumlah input yang sama untuk mencapai tahap kecekapan maksimum, iaitu 100\%.

JADUAL 1. Keputusan penganggaran analisis kecekapan teknik firma

\begin{tabular}{lccl}
\hline Pembolehubah & Koefisien & Ralat piawai & Nilai t \\
\hline Pintasan & 6.276 & 0.737 & $8.521 * * *$ \\
lnModal $(\mathrm{K})$ & 0.433 & 0.064 & $6.719 * * *$ \\
lnBuruh $(\mathrm{L})$ & 0.259 & 0.087 & $2.969 * *$ \\
Sigma-kuasa dua $\left(\sigma^{2}\right)$ & 1.215 & 0.333 & $3.653 * * *$ \\
Gamma $(\gamma)$ & 0.569 & 0.277 & $2.504 * *$ \\
Fungsi log-likelihood & -167.549 & & \\
LR test of one-sided error & 1.159 & & \\
Min kecekapan teknik & 0.576 & & \\
\hline
\end{tabular}

Nota: $* * *$ signifikan pada aras keertian $1 \%$, ** signifikan pada aras keertian 5\%.

\section{ANALISIS DESKRIPTIF}

Jadual 2 menunjukkan analisis deskriptif berhubung latar belakang firma/syarikat dan pengusahanya yang terdiri daripada majikan atau pengurus. Hampir keseluruhan firma/syarikat terdiri daripada sektor swasta, iaitu mewakili 99.2\%, sementara firma/syarikat kerajaan hanya $0.8 \%$. Maklumat berhubung firma/syarikat diperoleh sama ada daripada majikan atau pengurus. Majikan adalah pengusaha/pemilik perniagaan yang memiliki syarikat tersebut sepenuhnya, sementara pengurus adalah mereka yang dilantik oleh pemilik syarikat. Daripada keseluruhan majikan/pengurus di sektor swasta, sejumlah $62.8 \%$ adalah mereka yang memiliki syarikat sendiri, sementara 37.2\% adalah pengurus yang dilantik oleh syarikat. Sejumlah $56.9 \%$ diwakili oleh majikan/pengurus lelaki, sementara
$43.1 \%$ adalah perempuan. Berdasarkan kaum, sejumlah $50.8 \%$ adalah majikan/pengurus kaum Cina, diikuti kaum Melayu (47.7\%) dan kaum India (1.5\%). Bagi tahap pendidikan pula, $71.5 \%$ memiliki kelayakan akademik di peringkat diploma, ijazah dan setara dengannya, diikuti dengan tahap pendidikan menengah sejumlah $28.5 \%$.

Berhubung latar belakang firma/syarikat pula, sejumlah 56.2\% terdiri daripada firma/syarikat cawangan, diikuti dengan status ibu pejabat sebanyak $30.8 \%$, anak syarikat $(6.2 \%)$ dan $6.8 \%$ adalah lain-lain. Majoriti syarikat yang terlibat dalam kajian ini mempunyai jumlah pekerja kurang daripada 30 orang, iaitu sejumlah $73.0 \%$. Ini menunjukkan bahawa majoriti syarikat perkhidmatan berada dalam kategori firma/syarikat kecil. Walau bagaimanapun, saiz firma/syarikat tidak menjadi faktor utama dalam mempengaruhi nilai jualan yang diperoleh setiap tahun. Sungguhpun mempunyai saiz operasi yang kecil, namun jika firma mampu mengagih dan menggunakan input yang ada secara cekap, maka firma mampu untuk menghasilkan output yang maksimum. Ini boleh dilihat dari segi perolehan/hasil, di mana sejumlah $3.8 \%$ mendapat perolehan yang tinggi, iaitu melebihi RM3 juta setahun, manakala $34.6 \%$ mendapat perolehan antara RM300,000-RM3 juta dan selebihnya $61.5 \%$ mendapat perolehan kurang daripada RM300,000 setahun.

\section{ANALISIS KESAHAN DAN KEBOLEHPERCAYAAN}

Analisis kesahan menumpu (convergence validity) dibuat dengan melihat kepada faktor muatan (loading factor) dan nilai purata varians diekstrak (AVE: average variance extracted) untuk setiap indikator dan konstruk yang digunakan dalam kajian ini (lihat Jadual 3). Selanjutnya ujian kesahan (discriminant validity) dan kebolehpercayaan (reliability test) dianggar menerusi indikator kebolehpercayaan komposit (CR: composite reliability) seperti yang dipaparkan di dalam Jadual 4. Turut dipaparkan ialah nilai koefisien alfa Cronbach.

Merujuk Jadual 3, setiap indikator menunjukkan nilai faktor muatan adalah melebihi 0.7 , iaitu nilai yang dicadangkan oleh Hair et al. (2017). Justeru itu, terdapat indikator bagi setiap konstruk yang perlu digugurkan kerana tidak memenuhi syarat tersebut. Daripada jumlah keseluruhan indikator sebanyak 46 item, hanya 27 indikator sahaja yang dapat digunakan dalam kajian ini berdasarkan nilai faktor muatan yang harus melebihi 0.7 . Bagi nilai AVE pula, nilai minimum yang dicadangkan juga harus melebihi 0.5 (Hair et al. 2017). Nilai AVE bertujuan mengukur varians yang telah diperoleh menerusi indikator relatif, di samping sebagai pengukuran kepada ralat. Keputusan menunjukkan taburan nilai AVE bagi setiap konstruk adalah dalam lingkungan 0.568-0.851. Keputusan ini menunjukkan kesemua konstruk berupaya memberi pengukuran yang baik berdasarkan nilai-nilai yang diperoleh (Hair et al. 2017). 
JADUAL 2. Profil syarikat dan pengusaha

\begin{tabular}{|c|c|c|c|c|c|}
\hline Latar belakang & Kategori & Bilangan & Peratus & Min & Sisihan piawai \\
\hline \multirow[t]{2}{*}{ Jantina } & Lelaki & 74 & 56.9 & 0.569 & 0.044 \\
\hline & Perempuan & 56 & 43.1 & & \\
\hline \multirow[t]{3}{*}{ Bangsa } & Melayu & 62 & 47.7 & 1.538 & 0.047 \\
\hline & Cina & 66 & 50.8 & & \\
\hline & India & 2 & 1.5 & & \\
\hline \multirow[t]{2}{*}{ Tahap pendidikan } & Sekolah menengah & 37 & 28.5 & 3.338 & 0.093 \\
\hline & Diploma/ijazah dan setara & 93 & 71.5 & & \\
\hline \multirow[t]{2}{*}{ Kategori sektor } & Swasta & 129 & 99.2 & 2.615 & \\
\hline & Kerajaan & 1 & 0.8 & & 0.044 \\
\hline \multirow[t]{4}{*}{ Status syarikat } & Ibu pejabat & 40 & 30.8 & 2.115 & 0.094 \\
\hline & Anak syarikat & 8 & 6.2 & & \\
\hline & Cawangan & 73 & 56.2 & & \\
\hline & Lain-lain & 9 & 6.9 & & \\
\hline \multirow[t]{4}{*}{ Bilangan pekerja } & $<5$ & 5 & 3.8 & 2.377 & 0.068 \\
\hline & $5-30$ & 90 & 69.2 & & \\
\hline & $31-75$ & 16 & 12.3 & & \\
\hline & $>75$ & 19 & 14.6 & & \\
\hline \multirow[t]{3}{*}{ Nilai perolehan setahun } & $<\mathrm{RM} 300,000$ & 80 & 61.5 & 1.423 & 0.050 \\
\hline & RM300,000 - 2.99 juta & 45 & 34.6 & & \\
\hline & $>$ RM3.0 juta & 5 & 3.8 & & \\
\hline
\end{tabular}

Nota: Berasaskan $\mathrm{N}=130$ buah firma.

JADUAL 3. Keputusan kesahan menumpu

\begin{tabular}{|c|c|c|c|c|c|c|c|}
\hline \multirow[t]{2}{*}{ Konstruk dan indikator } & \multicolumn{6}{|c|}{ Faktor muatan } & \multirow[t]{2}{*}{ AVE } \\
\hline & 1 & 2 & 3 & 4 & 5 & 6 & \\
\hline 1. Kemahiran bekerja secara berpasukan & & & & & & & 0.663 \\
\hline T1. Kerja berpasukan & 0.829 & & & & & & \\
\hline T2. Merancang kerja & 0.863 & & & & & & \\
\hline T3. Kepimpinan & 0.855 & & & & & & \\
\hline T4. Menyelaras kerja & 0.759 & & & & & & \\
\hline T5. Bekerjasama & 0.781 & & & & & & \\
\hline 2. Kemahiran berfikir dan menyelesaikan masalah & & & & & & & 0.758 \\
\hline B1. Mengenal pasti masalah & & 0.892 & & & & & \\
\hline B2. Menganalisis masalah & & 0.879 & & & & & \\
\hline B3. Membuat justifikasi dalam menyelesaikan masalah & & 0.856 & & & & & \\
\hline 3. Kemahiran beretika dan moral dalam profesion & & & & & & & 0.713 \\
\hline M1. Menilai kesan ekonomi terhadap amalan etika dan moral & & & 0.775 & & & & \\
\hline M2. Menilai kesan alam sekitar terhadap amalan etika dan moral & & & 0.842 & & & & \\
\hline M1. Menilai kesan sosiobudaya terhadap amalan etika dan moral & & & 0.775 & & & & \\
\hline M2. Mengamal etika dan moral dalam profesion & & & 0.823 & & & & \\
\hline M3. Melaksana tanggungjawab terhadap masyarakat dan negara & & & 0.714 & & & & \\
\hline M7. Mengamal integriti & & & 0.747 & & & & \\
\hline 4. Kemahiran berkomunikasi secara efektif & & & & & & & 0.568 \\
\hline K1. Menyampaikan idea secara lisan & & & & 0.775 & & & \\
\hline K2. Menyampaikan idea secara bertulis & & & & 0.738 & & & \\
\hline K3. Mendengar secara efektif & & & & 0.728 & & & \\
\hline K4. Bertukar idea/pandangan & & & & 0.815 & & & \\
\hline K5. Berunding untuk mencapai persetujuan & & & & 0.765 & & & \\
\hline 5. Kemahiran keusahawanan & & & & & & & 0.851 \\
\hline E1. Mengambil peluang keusahawanan & & & & & 0.922 & & \\
\hline E2. Mencipta peluang keusahawanan & & & & & 0.932 & & \\
\hline 6. Kemahiran pengurusan & & & & & & & 0.598 \\
\hline P1. Merancang matlamat & & & & & & 0.792 & \\
\hline P2. Menjalankan pelbagai tugas & & & & & & 0.838 & \\
\hline P3. Memahami implikasi kewangan apabila membuat keputusan & & & & & & 0.874 & \\
\hline P4. Membuat keputusan yang tepat apabila diperlukan & & & & & & 0.889 & \\
\hline P5. Menggalakkan komunikasi dua hala dan telus & & & & & & 0.903 & \\
\hline P6. Mengamalkan budaya kerja positif & & & & & & 0.805 & \\
\hline
\end{tabular}


Berdasarkan maklumat di dalam Jadual 4, ujian kebolehpercayaan merujuk kepada nilai koefisien alfa sebagai nilai yang mengukur ketekalan. Nilai koefisien alfa bagi kesemua konstruk adalah melebihi 0.8 , iaitu antara 0.829-0.924. Ini menunjukkan setiap konstruk kemahiran yang digunakan dalam kajian ini mempunyai konsistensi dalaman yang tinggi. Keputusan statistik ini selari dengan nilai yang dicadangkan, di mana nilai alfa harus 0.7 atau lebih tinggi supaya pembolehubah dianggap sebagai "boleh diterima" dalam kebanyakan situasi penyelidikan sains sosial (Nunally \& Berstein 1994). Nilai kebolehpercayaan komposit (CR) juga menilai konsistensi bagi setiap konstruk yang digunakan dalam kajian ini. Keputusan ujian CR adalah konsisten dengan nilai koefisien alfa, di mana setiap konstruk menunjukkan nilai yang tinggi antara $0.868-0.937$, adalah melebihi 0.7 seperti yang dicadangkan oleh Hair et al. (2017).

Jadual 5 menunjukkan ujian multikoleneariti yang dibuat menerusi nilai VIF (variance inflation factor). Nilai VIF bagi kesemua konstruk berada dalam lingkungan antara 1.021 hingga 1.355 , iaitu di bawah 5 memenuhi nilai yang disarankan oleh Hair et al. (2017). Hasil ujian menunjukkan setiap konstruk yang digunakan di dalam kajian ini tidak mempunyai masalah kolineariti. Selanjutnya, nilai min bagi setiap konstruk berada dalam skala 5.466 hingga 5.930 menunjukkan tahap kemahiran bagi kesemua konstruk berada dalam skala tinggi, iaitu melebihi skala 5 .

JADUAL 4. Keputusan ujian kesahan (HTMT) dan kebolehpercayaan

\begin{tabular}{|c|c|c|c|c|c|c|c|c|}
\hline \multirow[t]{2}{*}{ Konstruk } & \multicolumn{5}{|c|}{ Ujian kesahan (discriminant validity) } & \multicolumn{3}{|c|}{$\begin{array}{c}\text { Ujian } \\
\text { kebolehpercayaan }\end{array}$} \\
\hline & 1 & 2 & 3 & 4 & 5 & 6 & $\alpha$ & $\mathrm{CR}$ \\
\hline $\begin{array}{l}\text { 1. Kemahiran bekerja secara } \\
\text { berpasukan }\end{array}$ & 1 & & & & & & 0.876 & 0.907 \\
\hline \multirow{6}{*}{$\begin{array}{l}\text { 2. Kemahiran berfikir dan } \\
\text { menyelesaikan masalah } \\
\text { 3. Kemahiran beretika dan } \\
\text { moral dalam profesion } \\
\text { 4. Kemahiran berkomunikasi } \\
\text { secara efektif }\end{array}$} & 0.087 & 1 & & & & & & \\
\hline & $(0.081,0.203)$ & & & & & & 0.849 & 0.904 \\
\hline & 0.430 & 0.186 & & & & & & \\
\hline & $(0.295,0.576)$ & $(0.089,0.338)$ & 1 & & & & 0.924 & 0.937 \\
\hline & 0.120 & 0.119 & 0.125 & & & & & \\
\hline & $(0.105,0.269)$ & $(0.104,0.261)$ & $(0.099,0.269)$ & 1 & & & 0.829 & 0.868 \\
\hline \multirow[t]{2}{*}{ 5. Kemahiran keusahawanan } & 0.324 & 0.331 & 0.388 & 0.070 & & & & \\
\hline & $(0.163,0.504)$ & $(0.165,0.492)$ & $(0.237,0.546)$ & $(0.076,0.234)$ & 1 & & 0.838 & 0.919 \\
\hline \multirow[t]{2}{*}{ 6. Kemahiran pengurusan } & 0.370 & 0.150 & 0.453 & 0.125 & 0.381 & & & \\
\hline & $(0.197,0.555)$ & $(0.109,0.278)$ & $(0.289,0.609)$ & $(0.131,0.263)$ & $(0.236,0.530)$ & 1 & 0.871 & 0.899 \\
\hline
\end{tabular}

Nota: HTMT merujuk kepada Heterotrait-Monotrait Ratio discriminant validity. Nilai di dalam kurungan adalah nilai bagi selang keyakinan pada $5 \%$ dan $95 \%$.

JADUAL 5. Min, sisihan piawai dan multikolineariti

\begin{tabular}{lccc}
\hline \multicolumn{1}{c}{ Konstruk } & Min & Sisihan piawai & VIF \\
\hline Kemahiran bekerja secara berpasukan & 5.930 & 0.040 & 1.244 \\
Kemahiran berfikir dan menyelesaikan masalah & 5.727 & 0.042 & 1.138 \\
Kemahiran beretika dan moral dalam profesion & 5.745 & 0.045 & 1.355 \\
Kemahiran berkomunikasi secara efektif & 5.916 & 0.139 & 1.021 \\
Kemahiran keusahawanan & 5.466 & 0.022 & 1.273 \\
Kemahiran pengurusan & 5.765 & 0.034 & 1.280 \\
\hline
\end{tabular}

\section{KEPUTUSAN HIPOTESIS}

Jadual 6 menunjukkan dapatan kajian bagi keputusan hipotesis mengenai hubungan antara setiap kemahiran pekerja dengan tingkat kecekapan firma (lihat Rajah 1). Rajah 1 menunjukkan hubungan antara kedua-dua pembolehubah adalah model multi dimensi, di mana setiap kemahiran secara langsung/secara positif mempengaruhi tingkat kecekapan firma yang dikaji. Keputusan hipotesis menunjukkan konstruk kemahiran bekerja secara berpasukan adalah selari dengan hipotesis, iaitu signifikan pada aras keertian 10\%. Dapatan menunjukkan kemahiran bekerja secara berpasukan secara positif mempengaruhi tingkat kecekapan firma. Ini bermaksud dengan peningkatan $1 \%$ dalam kemahiran bekerja secara berpasukan akan mempengaruhi peningkatan dalam tingkat kecekapan sebanyak $0.213 \%$.

Walau bagaimanapun, kemahiran beretika dan moral dalam profesion dan kemahiran berkomunikasi secara efektif sungguhpun signifikan, namun mempengaruhi tingkat kecekapan secara negatif. Kedua-duanya signifikan pada aras keertian $10 \%$ dengan nilai koefisien masingmasing adalah -0.181 dan -0.165 . Hubungan yang negatif ini boleh dikaitkan dengan latihan yang disediakan oleh 
JADUAL 6. Keputusan hipotesis

\begin{tabular}{|c|c|c|c|c|}
\hline Hipotesis & Hubungan & Koefisien & Nilai-p & Keputusan \\
\hline $\mathrm{H}_{1}$ & $\begin{array}{l}\text { Kemahiran bekerja secara berpasukan secara positif mempengaruhi } \\
\text { tahap kecekapan teknik firma }\end{array}$ & 0.213 & $\begin{array}{c}0.091 \\
(1.695)^{*}\end{array}$ & Signifikan \\
\hline $\mathrm{H}_{2}$ & $\begin{array}{l}\text { Kemahiran berfikir dan menyelesaikan masalah secara positif } \\
\text { mempengaruhi tahap kecekapan teknik firma }\end{array}$ & -0.122 & $\begin{array}{c}0.210 \\
(1.256)\end{array}$ & $\begin{array}{l}\text { Tidak } \\
\text { signifikan }\end{array}$ \\
\hline $\mathrm{H}_{3}$ & $\begin{array}{l}\text { Kemahiran beretika dan moral dalam profesion secara positif } \\
\text { mempengaruhi tahap kecekapan teknik firma }\end{array}$ & -0.181 & $\begin{array}{c}0.089 \\
(1.703)^{*}\end{array}$ & Signifikan \\
\hline $\mathrm{H}_{4}$ & $\begin{array}{l}\text { Kemahiran berkomunikasi secara efektif secara positif mempengaruhi } \\
\text { tahap kecekapan teknik firma }\end{array}$ & -0.165 & $\begin{array}{c}0.078 \\
(1.767)^{*}\end{array}$ & Signifikan \\
\hline $\mathrm{H}_{5}$ & $\begin{array}{l}\text { Kemahiran keusahawanan secara positif mempengaruhi tahap } \\
\text { kecekapan teknik firma. }\end{array}$ & 0.126 & $\begin{array}{c}0.202 \\
(1.277)\end{array}$ & $\begin{array}{c}\text { Tidak } \\
\text { signifikan }\end{array}$ \\
\hline $\mathrm{H}_{6}$ & $\begin{array}{l}\text { Kemahiran pengurusan secara positif mempengaruhi tahap kecekapan } \\
\text { teknik firma. }\end{array}$ & -0.059 & $\begin{array}{c}0.664 \\
(0.435) \\
R^{2}=0.117\end{array}$ & $\begin{array}{c}\text { Tidak } \\
\text { signifikan }\end{array}$ \\
\hline
\end{tabular}

Nota: Nilai di dalam kurungan adalah nilai -statistik. * ialah nilai p yang signifikan pada aras keertian $10 \%$.

pihak majikan berkemungkinan adalah latihan umum yang akhirnya lebih memberi kesan kepada pekerja dari segi mendapatkan pekerjaan lain. Sementara kemahiran berfikir dan menyelesaikan masalah, kemahiran keusahawanan dan kemahiran pengurusan didapati tidak signifikan dalam mempengaruhi tingkat kecekapan firma.

Dapatan kajian ini disokong oleh kajian Rahman et al. (2011) yang memperoleh kemahiran mengurus dan kemahiran keusahawanan dalam kalangan pelajar kejuruteraan mencatatkan skor yang paling rendah, sementara kemahiran bekerja secara berkumpulan mendapat skor paling tinggi dalam kalangan pelajar kejuruteraan di Malaysia. Ini disebabkan sesetengah kemahiran generik boleh dibina semasa pelajar mengikuti program di peringkat universiti/kolej, manakala sesetengahnya pula tidak berpeluang dalam mendalami sesetengah kemahiran. Misalnya, kemahiran keusahawanan dan kemahiran pengurusan boleh didalami bagi pelajar yang mengambil program keusahawan, sebaliknya pelajar yang mengambil program lain kemungkinan tidak berpeluang untuk mendalaminya.

Nilai $\mathrm{R}^{2}$ diperoleh sebanyak 0.117 memperlihatkan bahawa hanya $11.7 \%$ daripada varian dalam kecekapan teknik firma dapat dijelaskan oleh keenam-enam konstruk keperluan kemahiran yang digunakan sebagai pembolehubah bebas dalam kajian ini.

\section{RUMUSAN DAN CADANGAN}

Secara keseluruhan, kajian ini merumuskan beberapa kesimpulan. Pertama, kajian ini memperoleh dapatan bagi tahap kecekapan firma perkhidmatan yang dikaji secara relatifnya masih pada tahap kecekapan yang rendah. Keputusan menunjukkan purata kecekapan teknik bagi keseluruhan firma perkhidmatan yang dikaji hanya 0.576 . Berdasarkan nilai ini, firma perlu mencapai tahap pengeluaran yang lebih besar dengan jumlah penggunaan input sedia ada supaya kecekapan dapat ditingkatkan. Kedua, kepentingan aspek kemahiran generik sememangnya tidak dinafikan sama sekali dalam kalangan majikan yang ingin mengambil pekerja. Bagi kajian ini, dapatan bagi keperluan kemahiran dalam mempengaruhi tingkat kecekapan firma hanya positif bagi aspek kemahiran bekerja secara berpasukan.

Oleh yang demikian, berdasarkan dapatan kajian ini, beberapa aspek harus diteliti semula, terutamanya sistem pendidikan sedia ada harus mengintegrasikan kemahiran generik dengan setiap tahap pencapaian dalam pendidikan supaya seiring dengan kualiti modal manusia yang ingin dibangunkan. Ini boleh dilakukan di peringkat pra sekolah lagi sehinggalah ke peringkat institusi pengajian tinggi (IPT) supaya graduan dilengkapi dengan pelbagai kemahiran yang diperlukan oleh majikan masa kini. Berdasarkan dapatan kajian ini, sungguhpun universiti/ kolej terlibat dalam mencungkil bakat/membina sesuatu kemahiran pelajar, namun penglibatan pihak swasta (firma/syarikat) amat diperlukan dalam bekerjasama untuk memberi latihan kepada pelajar-pelajar.

Di samping sistem pendidikan, aspek latihan di peringkat firma khususnya, amat membantu pekerja dalam meningkatkan kemahiran sesuai dengan keperluan firma/organisasi. Oleh kerana jenis kemahiran yang dikaji melibatkan kemahiran generik, latihan sambil bekerja (on-the-job training) adalah paling sesuai di dalam firma/ organiasasi, di samping penjimatan kos latihan. Pihak pengurusan firma/syarikat juga perlu lebih arif dan proaktif dalam mempertingkat kemahiran mengikut keperluan seiring dengan ekonomi berasaskan pengetahuan dan revolusi perindustrian 4.0. IPT juga disaran agar melakukan penilaian semula terhadap kursus-kursus yang ditawarkan supaya seiring dengan kehendak majikan dan ini dapat meningkatkan kebolehpasaran graduan. Seiring dengan aspek kemahiran insaniah yang merupakan agenda utama dalam pembangunan sumber manusia, pihak kerajaan sememangnya menekankan pembangunan dalam modal insan minda kelas pertama dan ini patut mendapat sokongan penuh daripada masyarakat. 


\section{PENGHARGAAN}

Artikel ini adalah sebahagian daripada dapatan kajian Projek Penyelidikan Sumber Baharu Penjanaan Kekayaan dan Keperluan Kemahiran bagi Ekonomi Berpendapatan Tinggi di bawah dana penyelidikan universiti (AP-2013012).

\section{RUJUKAN}

Abdullah, M.A. 1997. Industri Kecil di Malaysia, Pembangunan dan Masa Depan. Kuala Lumpur: Dewan Bahasa dan Pustaka.

Abdullah. M.F., Ismail, R., Sulaiman, N. \& Abdul Talib, B. 2017. Technical efficiency in transport manufacturing firms: Evidence from Malaysia. Asian Academy of Management Journal 22(1): 57-77.

Abdullah. M.F., Wei Sieng, L. \& Isa, M.H. 2018. Technical efficiency in Malaysian textile manufacturing industry: A stochastic frontier analysis (SFA) approach. International Journal of Economics and Management 12(2): 407-419.

Abu Mansor, S. \& Radam, A. 2000. Productivity and efficiency performance of the Malaysian life insurance industry. Jurnal Ekonomi Malaysia 34: 93-105.

ACNielsen Research Services. 2000. Employer satisfaction with graduate skills. Research Report by the Department of Education, Training and Youth Affairs, Commonwealth of Australia.

Adni., M.A., Omar, A. \& Mohd Tarmizi, R. 2012. The performance of insurance industry in Malaysia: Islamic visà-vis Conventional insurance. Journal of Islamic Banking and Finance 29(4): 40-49.

Ameerudin, R. 2001. Faktor-faktor pemilihan pekerja dalam industri perbankan. Kertas Ilmiah, Ijazah Sarjana Pendidikan (Teknikal), Fakulti Kejuruteraan, UTHM.

Applanaidu S-D., Samsudin S., Ali, J., Dash, U. \& Chik, A.R. 2014. Technical and scale efficiency of public district hospitals in Kedah, Malaysia: AData Envelopment Analysis. Journal of Health Management 16(3): 327-335.

Archer, W. \& Davison, J. 2008. Graduate Employability: The View of Employer. London: The Council for Industry and Higher Education.

Arsat, M. \& Abd Kadir, N. 2010. Kemahiran generik dalam faktor pemilihan jurutera mengikut perspektif industri pembinaan. Fakulti Pendidikan, Universiti Teknologi Malaysia.

Ashton, D. \& Sung, J. 2002. Supporting Workplace Learning for High Performance Working. Geneva: International Labour Office.

Banci Penyiasatan Tenaga Buruh. 2015. Putrajaya: Jabatan Perangkaan Malaysia.

Banci Penyiasatan Tenaga Buruh. 2017. Putrajaya: Jabatan Perangkaan Malaysia.

Bank Negara. 2017. Annual Report 2017, Bank Negara Malaysia. Kuala Lumpur.

Baten, M.A., Kamil, A.A. \& Fatama, K. 2009. Technical efficiency in stochastic frontier production model: An application to the manufacturing industry in Bangladesh. Australian Journal of Basic and Applied Sciences. 3(2): 1160-1169.

Battese, G.E. \& Coelli, T.J. 1995. Amodel for technical inefficiency effects in a stochastic frontier production function for panel data. Empirical Economics 20: 325-332.
Bessent, A. \& Bessent, W. 1979. Determining the comparative efficiency of schools through data envelopment analysis. Research Report CCS 361 Center for Cybernetic Studies. The University of Texas, United States.

Bottazzi, G., Secchi, A. \& Tamagni, F. 2006. Productivity, profitability and financial performance: A firm level comparative analysis of Italian manufacturing and services. Scuola Superiore Sant'Anna.

Chen,T., Chen,C. \& Peng, S. 2008. Firm operation performance analysis using data envelopment analysis and balanced scorecard: A case study of a credit cooperative bank. International Journal of Productivity and Performance Management 57(7): 523-539.

Coelli, T., Prasad, D.S. \& Battese, G.E. 1998. An Introduction to Efficiency and Productivity Analysis. USA: Kluwer Academic Publishers.

Coelli, T.J. 1996. A guide to FRONTIER version 4.1: A computer program stochastic frontier production and cost function estimation. CEPA Working Paper 07.

Constantine E.P. 2006. The business of globalization and the globalization of business. Journal of Comparative International Management 9(1): 3-18.

Farrel, M.J. 1957. The measurement of productive efficiency. Journal of Royal Statistical Society Series A (General) 120: 253-281.

Field, L. \& Mawer, G. 1996. Generic skills requirements of the high performance workplace. Sydney: Department of Training and Education Co-ordination.

Fu, W.G., Sun, S. \& Zhou, Z.Y. 2011. Technical efficiency of food processing in China: The case of flour and rice processing. China Agricultural Economic Review 3(3): 321-334.

Gallacher, M. 2001. Education as an input in agricultural production, CEMA Working Papers 189, Universidad de CEMA.

Grugulis, I. \& Stoyanova, D. 2010. Skills and performance. British Journal of Industrial Relations 49(3): 515-536.

Hair., J.F., Tomas, G.M., Hult, C.R. \& Sarstedt, M. 2017. A Primer on Partial Least Squares Structural Equation Modeling (PLS-SEM). $2^{\text {nd }}$ Edition. United States: Sage Publication.

Hollingsworth, B. 2008. The measurement of efficiency and productivity of health care delivery. Health Economics 17(10): 1107-1128.

Huang, C.J. \& Liu, J.T. 1994. Estimation of a non-neutral stochastic frontier production function. Journal of Productivity Analysis 5: 171-180.

Husain, M.Y. \& Mustapha, R. 2009. Penilaian kemahiran employability dalam kalangan pelajar kejuruteraan politeknik kementerian pengajian tinggi Malaysia. Seminar Kebangsaan Pembangunan Keusahawanan UKM 2009, 8-9 December. Kuala Lumpur.

Isabel, R. \& Tatiane, M. 2011. Public school efficiency using data envelopment analysis: An empirical application for Brazil. ERSA conference papers, European Regional Science Association.

Ismail, R. \& Sulaiman, N. 2007. Technical efficiency in Malay manufacturing firms. International Journal of Business and Society 8(2): 47-62

Ismail, R. \& Nyet Fung, C. 2002. Sumbangan produktiviti keseluruhan terhadap output industri skel kecil dan sederhana: Satu analisis perbatasan stokastik. Jurnal Analisis 9: 77-99. 
Ismail, R. \& Tendot, N. 2008. Analisis kecekapan teknikal firma melayu dalam sektor pembuatan Malaysia. International Journal of Management Studies 15(2): 143-163.

Ismail, R. \& Zainal Abidin, S. 2006. Analisis tahap dan penentu kecekapan teknikal firma Melayu sektor perkhidmatan. Media Ekonomi Trisakti 11(1): 45-57.

Ismail, R., Sulaiman, N., Agus, A. \& Ahmad, F. 2015. Labour demand elasticity and manpower requirement in Malaysian service sector. International Review of Business Research Papers 11(2): 13-25.

Jackling, B. \& Lange. 2009. Do accounting graduates' skills meet the expectations of employers? A matter of covergence of divergence. Accounting Education: An International Journal 18(4): 369-385.

Jajri, I., Othman, P., Kian Teng, K. \& Ismail, N.A. 1992. Requirements of economic graduates by the public sector: A survey. Dalam Program Ekonomi di Universiti: Suatu Penilaian Semula. Disunting oleh A.B. Salleh, P. Othman \& M. Alias. Pascasidang Seminar Kebangsaan, Fakulti Ekonomi, UKM

Jones, P. 1994. Are manufacturing workers really worth their pay? Working Paper 94-12, Centre for the Study of African Economies, Oxford University.

Kementerian Kewangan Malaysia. 2017. Laporan Ekonomi 2017/2018. Putrajaya: Percetakan Nasional Malaysia Berhad Kuala Lumpur.

Kirkley, J., Squires, D. \& Strand, I. 1998. Characterizing managerial skill and technical efficiency in a fishery. Journal of Productivity Analysis 9(2): 145-160.

Kisaka, S.E., Kising, N.N. \& Wafubwa, B.M. 2014. Managerial skills and technical efficiency of commercial banks in Kenya. Research Journal of Finance and Accounting 5(14): 117-135.

Kumbhakar, S.C., Ghosh, S. \& McGuckin, J.T. 1991. A generalised production frontier approach for estimating determinants of inefficiency in U.S dairy farms. Journal of Business and Economic Statistics 9(3): 279-286.

Makhbul, M.Z. \& Hasun, M.F. 2007. Amalan pengambilan dan pemilihan pekerja: Tinjauan ke atas firma terpilih di sektor perkilangan. Intenational Journal of Management Studies 14(2): 143-162.

Md Zabid, A. \& Samsinar, M.S. 1996. The perceptions and expectations of employers on local graduates. Proceeding on Management Education Seminar. Kuala Lumpur.

Md. Saad, N., Abd. Majid, M.S., Mohd. Yusof, R., Duasa, J. \& Abdul Rahman, A.R. 2007. Measuring efficiency of insurance and takaful companies in Malaysia using Data Envelopment Analysis. Economics 11(1): 5-26.

Mohd. Noor, Z. \& Ismail, R. 2007. Analisis kecekapan teknikal dalam industri skel kecil dan sederhana di Malaysia. International Journal of Management Studies 14(1): 199-218.

Nayar, P. \& Ozcan A. 2008. Data Envelopment Analysis comparison of hospital efficiency and quality. Journal Medical System 32(3): 193-199.

Nunamaker, T.R. \& Lewin, A. Y. 1983. Measuring routine nursing service efficiency: A comparison of cost per patient day and data envelopment analysis models/comment. Health Services Research 18(2): 183-208.

Nunnally, J.C. \& Bernstein, I.H. 1994. Psychometric Theory. 3rd edition. New York: McGraw- Hill.
Porter, M.E. 2004. The microeconomic foundations of prosperity: Findings from the Microeconomic Competitions Index, World Economic Forum, Geneva.

Radam, A., Baharom, A.H., Dayang-Affizzah, A.M. \& Ismail, F. 2009. Effect of mergers on efficiency and productivity: Some evidence for banks in Malaysia. The IUP Journal of Bank Management 8(1): 31-46.

Rahman, S., Mokhtar, S.B., Mohd Yasin, R. \& Mohd Hamzah, M.I. 2011. Generic skills among technical students in Malaysia. Procedia Social and Behavioral Sciences 15: 3713-3717.

Reifschneider, D. \& Stevenson, R. 1991. Systematic departures from the frontier: A framework for the analysis of firm inefficiency. International Economic Review 32: 715723.

Said, A. 2006. Knowledge surveys: An introduction. Paper presented on August 30 in the Faculty of Education UTM Skudai Colloquium.

Salleh, M.I. 2012. An empirical analysis of efficiency and productivity changes in Malaysian public higher education institutions. Unpublished PhD. Thesis, School of Economics, University of Wollongong, Australia.

Samsudin, S., Applanaidu, S.D., Jaafar, A.S., Ali, J. \& Majid, R. 2014. Performance of public hospitals in Malaysia and its determinants: An analysis using Data Envelopment Analysis and Tobit Model. Handbook on the Emerging Trends in Scientific Research 807-815.

Schwab, K. 2017. The Fourth Industrial Revolution. United States of America: Crown Business.

Sherman, H. 1984. Hospital efficiency measurement and evaluation: Empirical test of a new technique. Medical Care 22(10): 922-938.

Sulaiman, N. \& Ismail, R. 2007. Kecekapan teknik firma usahawan Melayu dalam sektor perkhidmatan, Jurnal Teknologi 46(E): 113-130.

Sulaiman, N., Ismail, R. \& Saukani, N. 2016. Labour demand elasticity and manpower requirements of skilled labour in Malaysian manufacturing sector. International Journal of Economic Research 13(5): 2235-2250.

Sulaiman, N., Md Yusof, S. \& Ismail, R. 2015. Tahap kecekapan dan penentu pencapaian prestasi staf akademik: Kajian kes UKM. Geografia Malaysian Journal of Society and Space 11(10): 37-50.

Sung, J. \& Ramos, C.R. edt. 2014. Skills Strategy for Inclusive Society: The roles of the State, the Enterprises and the Workers. Singapore: Institute for Adult Learning.

Ugur, A. 2004. Technical efficiency in Irish manufacturing industry 1991-1999. Department of Economics, Trinity College, Dublin.

Viswanathan, K.K., Jeon, Y., Omar, I. H., Kirkley, J., Squires, D. \& Susilowati, I. 2000. Technical efficiency and fishing skill in developing countries: The Kedah, Malaysia trawl fishery. International Institute for Fisheries Economics and Trade (IWET), Oregon, USA

World Bank. 2003. Lifelong Learning in the global knowledge economy: Challenges for Developing Countries. A World Bank Report, Washington, D.C.

Yauheniyavarabyova \& Jonasschreyögg. 2013. OECD countries international comparisons of the technical efficiency of the hospital sector: Panel data analysis of OECD Countries using parametric and non-parametric approaches. Health Policy 112(1-2): 70-79. 
Yussof, I., Sulaiman, N., Long Ahmad, M.S. \& Ismail, R. 2014. Impact of labour productivity of the National Key Economic Areas (NKEAs). Journal of Contemporary Issues and Thought 4: 137-155.

Noorasiah Sulaiman (penulis koresponden)

Fakulti Ekonomi dan Pengurusan

Universiti Kebangsaaan Malaysia

43600 UKM Bangi, Selangor, MALAYSIA.

E-Mel: rasiahs@ukm.edu.my

Nursaliha Abd Ghafar

Fakulti Ekonomi dan Pengurusan

Universiti Kebangsaaan Malaysia

43600 UKM Bangi, Selangor, MALAYSIA.

E-Mel: nursalihaabdghafar@yahoo.com 